\title{
Pharmacological restraint of red-footed tortoises using combinations of ketamine, midazolam and butorphanol
}

\author{
Contenção farmacológica com associações de cetamina, \\ midazolam e butorfanol em jabutis-piranga
}

Eduardo Raposo Monteiro ${ }^{[a]}$, Eduardo Lázaro de Faria da Silva ${ }^{[b]}$, Maria Guadalupe Dias Pestana Santos ${ }^{[b]}$, João Luiz Rossi Júnior ${ }^{[a]}$, Paulo Dias Ferreira Júnior ${ }^{[c]}$

[a] Médicos-veterinários, professores Doutores do curso de Medicina Veterinária e mestrado em Ciência Animal, Centro Universitário Vila Velha (UVV), Vila Velha, ES - Brasil, e-mails: eduardo.raposo@uvv.br; joão.rossi@uvv.br

[b] Acadêmicos do curso de Medicina Veterinária, Centro Universitário Vila Velha (UVV), Vila Velha, ES - Brasil, e-mail: eduardo_lfs@yahoo.com.br; tulipaaaa@hotmail.com

[c] Engenheiro geólogo, professor Doutor do mestrado em Ecologia de Ecossistemas, Centro Universitário Vila Velha (UVV), Vila Velha, ES - Brasil, e-mail: pdfj@uvv.br

\begin{abstract}
The present study tested the association of ketamine, midazolam and butorphanol on the pharmacological restraint of red-footed tortoises. Eight animals were used, which were submitted to three different intramuscular treatments every 15 days: ketamine $30 \mathrm{mg} / \mathrm{kg}(\mathrm{C})$; ketamine $30 \mathrm{mg} / \mathrm{kg}+$ midazolam $1 \mathrm{mg} / \mathrm{kg}$ (CM) e ketamine $30 \mathrm{mg} / \mathrm{kg}$ + butorphanol $1 \mathrm{mg} / \mathrm{kg}$ (CB). The variables evaluated were: period of restraint, degree of analgesia and muscle relaxation, skin temperature and recovery time. There were no significant differences among treatments for the onset of anesthesia and the degree of muscle relaxation. None of the treatments provided surgical anesthesia. Recovery was prolonged in treatments using CM and CB. However, only the CM treatment differed significantly $(\mathrm{p}<0.05)$ in comparison to treatment $C$. The temperature did not change over 60 minutes for all treatments. Under the conditions of this study, the combination of midazolam or butorphanol did not result in better analgesia and muscle relaxation of red-footed tortoises, and it prolonged their recovery period.
\end{abstract}

Keywords: Chelonoidis carbonaria. Dissociative anesthetics. Analgesia. Opioids.

\section{Resumo}

O presente estudo objetivou testar a associação de cetamina, midazolam e butorfanol visando à contenção em jabutis-piranga. Foram utilizados oito animais, os quais foram quinzenalmente submetidos a três tratamentos (via intramuscular): cetamina $30 \mathrm{mg} / \mathrm{kg}$ (grupo controle); cetamina $30 \mathrm{mg} / \mathrm{kg}+$ midazolam $1 \mathrm{mg} / \mathrm{kg}$ (grupo CM) e cetamina $30 \mathrm{mg} / \mathrm{kg}+$ butorfanol $1 \mathrm{mg} / \mathrm{kg}$ (grupo CB). Foram avaliadas as seguintes variáveis: o período de latência, o grau de analgesia, o relaxamento muscular, a temperatura da pele e o período de recuperação. Não foram observadas diferenças significativas entre os tratamentos nos períodos de latência e grau de relaxamento muscular. Nenhum dos tratamentos proporcionou anestesia cirúrgica. O período de recuperação foi 
mais longo nos tratamentos CM e CB, embora somente o tratamento CM tenha diferido significativamente $(p<$ $0,05)$ em relação ao tratamento C. A temperatura não se alterou ao longo de 60 minutos em nenhum dos tratamentos. Nas condições do presente estudo, a associação do midazolam ou butorfanol não resultou em melhor analgesia ou relaxamento muscular e prolongou a recuperação anestésica em jabutis-piranga.

Palavras-chave: Chelonoidis carbonaria. Anestésicos dissociativos. Analgesia. Opioides.

\section{Introduction}

Anesthesia of testudinata is often required to facilitate the handling of these animals. Routine procedures such as physical examination, collection of biometric data, diagnostic imaging and sampling of biological material such as blood and mouth swabbing are common practices employed in zoos and in the care of captive animals. Often, sampling is not possible without the use of chemical restraint (BIENZLE; BOYD, 1992).

Dissociative anesthetics, such as ketamine, produce sedation at doses below $30 \mathrm{mg} / \mathrm{kg}$ (IM) and may provide surgical anesthesia at doses above $55 \mathrm{mg} / \mathrm{kg}$ (SCHUMACHER, 1996, 2007). One of the main advantages of using dissociative anesthetics in testudinata is the possibility of their administration by intramuscular injection whereas other agents, such as propofol, are for intravenous use only (MCARTHUR, 2004; SCHUMACHER, 2007).

Although many veterinarians use ketamine in combination with benzodiazepines and opioids in the routine management of testudinata to improve analgesia and muscle relaxation, there are few experimental or clinical studies evaluating the effectiveness of these combinations. This study aimed to compare pharmacological restraint of red-footed tortoises using ketamine alone and its combination with midazolam or butorphanol.

\section{Materials and methods}

This study was approved by the Institutional Animal Research Ethical Committee (protocol 100/2010). Eight free-living red-footed tortoises (Chelonoidis carbonaria [Spix, 1824]) weighing $4.8 \pm$ $1.2 \mathrm{~kg}$ (mean $\pm \mathrm{SD}$ ) were used in this study. The animals were confiscated by IBAMA and donated to the Institution's Animal Hospital for health status evaluation and to perform periodic checks before releasing them. The animals were randomly assigned to receive three different treatments on separate occasions, with 15-day washout intervals, as follows: treatment C, ketamine $30 \mathrm{mg} / \mathrm{kg}$ (Cetamin 10\%, Syntec, Cotia, $\mathrm{SP}$, Brazil); treatment CM, ketamine $30 \mathrm{mg} / \mathrm{kg}$ in combination with midazolam $1 \mathrm{mg} / \mathrm{kg}$ (Dormire $5 \mathrm{mg}$ / $\mathrm{mL}$, Cristália, Itapira, SP, Brazil); treatment CB, ketamine $30 \mathrm{mg} / \mathrm{kg}$ in combination with butorphanol $1 \mathrm{mg} / \mathrm{kg}$ (Torbugesic 1\%, Fort Dodge, Iowa, USA).

All treatments were administered intramuscularly in the thoracic limb. Skin temperature was measured before drug administration and 60 minutes after treatment using a digital infrared thermometer (Infraterm mod. 7660, Incoterm, Porto Alegre, RS, Brasil); the thermometer's sensor was directed toward the pectoral muscles. Onset of pharmacological restraint was considered the time elapsed from the administration of drug until the relaxation of the animal's head. The degree of muscle relaxation of the neck and limbs was assessed using a visual analogue scale (VAS), which consisted of a 10$\mathrm{cm}$ line representing no muscle relaxation at the left end and the best muscle relaxation possible at the right end. An observer was responsible for placing a mark on the line that corresponded to the degree of muscle relaxation. The distance $(\mathrm{cm})$ between the left end of the scale and the mark was considered the degree of muscle relaxation. A rat tooth forceps was used to assess the degree of analgesia by clamping the skin at the forelimb during several time points within 60 minutes after drug treatment. At this moment, withdraw of limb or head movements in response to the stimulus were considered positive responses.

Recovery time was defined as the period from administration of treatments to the first spontaneous ambulation. A single observer, who was unaware of which treatment was administered, was responsible for evaluating all variables on each occasion. After that, comparisons between treatments for nonparametric 
variables were performed by a Friedman or KruskalWallis and a Dunn's test for multiple comparisons, whereas parametric variables were analyzed by repeated measures of analysis of variance (ANOVA) followed by Tukey's test. Differences were considered significant when $\mathrm{p}<0.05$.

\section{Results}

The results of this study are shown on Table 1 . There was no significant difference between treatments in the degree of muscle relaxation and in skin temperature before drug administration and $60 \mathrm{~min}$ utes thereafter. Onset of restraint appeared to be faster with CM treatment, but the difference from other treatments was not statistically significant $(\mathrm{p}=0.36-$ Friedman's test). Recovery was faster in treatment C, a significant difference was observed between treatments $\mathrm{C}$ and $\mathrm{CM}(\mathrm{p}<0.01)$, and also between $\mathrm{C}$ and CB ( $p<0.01)$. On all occasions, the responses to pinching the skin were considered positive.

\section{Discussion}

Results of the present study suggested that none of the treatments provided surgical anesthesia in red-footed tortoises. However, all treatments provided pharmacological restraint and muscle relaxation suitable for the collection of biological material such as jugular venous blood, oral swabs and biometric tests. The combination of an analgesic (butorphanol) or a muscle relaxant (midazolam) did not improve analgesia or muscle relaxation, but they prolonged the animal recovery from anesthesia.

It was previously reported that ketamine at $30 \mathrm{mg} / \mathrm{kg}$ causes sedation, poor muscle relaxation and mild analgesia in testudinata (SCHUMACHER, 1996, 2007). Doses above $55 \mathrm{mg} / \mathrm{kg}$ are required to achieve surgical analgesia resulting in extremely prolonged recoveries, which may take up to 96 hours (SCHUMACHER, 1996). Therefore, the combination of ketamine with analgesics and opioids is recommended to reduce the dose of ketamine necessary for surgical analgesia (SCHUMACHER, 1996, 2007).

The present results showed that the combination of butorphanol at $1 \mathrm{mg} / \mathrm{kg}$ did not improve analgesia when compared with ketamine alone. One possible explanation for this finding might be the opioid of choice. Although butorphanol is recommended for administration in testudinata (SCHUMACHER, 1996, 2007), this is an opioid which acts as an agonist at kappa receptors and as an antagonist at $\mu$ receptors (WAGNER, 2002).

In a study published recently, it was reported that the thermal limb withdrawal latencies were increased by administration of $\mu$ agonists (suggesting analgesia) in turtles, whereas kappa agonists decreased or did not change this response. The authors suggested that thermal antinociception in turtles appears to be attributable mainly to the activation of $\mu$ receptors (SLADKY et al., 2009). Perhaps the use of a pure $\mu$-receptor agonist, such as morphine, could be used to achieve a better degree of analgesia.

Besides the use of analgesics, it is also recommended the use of ketamine in combination with muscle relaxants, such as alpha- 2 agonists and benzodiazepines to improve muscle relaxation (SCHUMACHER, 1996, 2007). However, the results presented in this study showed that the combination of butorphanol or midazolam did not result in better degree of muscle relaxation. One possible explanation for these results might be the method used for assessing the degree of muscle relaxation. It is still debatable which is the best method to assess subjective variables such as pain, sedation and muscle relaxation. A previous study reported that the VAS scale was more sensitive in assessing acute pain in dogs than numeric scales, especially when a single observer is responsible for all assessments (MATHEWS, 2000). However, there is a possibility that the VAS scale was not sensitive enough to detect differences of muscle relaxation among treatments in this study.

Body temperature in reptiles is typically lower than in mammals and their optimal temperature ranges between $25^{\circ} \mathrm{C}$ and $30{ }^{\circ} \mathrm{C}$ (HOERNERCUBAS; BAPTISTOTTE, 2007). In the present study, the baseline temperature was $26.5{ }^{\circ} \mathrm{C}$ (average of the three groups) and the environmental temperature was approximately $25{ }^{\circ} \mathrm{C}$ during all days of experiment. Since the body temperature differs from environmental temperature in just a few degrees, the heat loss is slow, and no significant decrease in body temperature was observed in the animals used in this study during the 60-minute evaluation period. 
Table 1 - Variables measured at eight red-footed tortoises given $30 \mathrm{mg} / \mathrm{kg}$ of ketamine (C), $30 \mathrm{mg} / \mathrm{kg} \mathrm{ketamine}+1 \mathrm{mg} / \mathrm{kg}$ of midazolam (CM) and $30 \mathrm{mg} / \mathrm{kg}$ ketamine $+1 \mathrm{mg} / \mathrm{kg}$ of butorphanol (CB). All treatments were administered intramuscularly. Nonparametric variables (onset of anesthesia, muscle relaxation and recovery from anesthesia) are expressed as medians (interquartile range). Values of temperature at baseline and at 60 minutes are expressed as means \pm SD

\begin{tabular}{lccc}
\hline & \multicolumn{3}{c}{ Treatment } \\
\cline { 2 - 4 } & C & CM & CB \\
\hline Onset of anesthesia $(\mathbf{m i n})$ & $13.5(6.5-16.5)$ & $9.0(5.5-10.0)$ & $16.0(7.8-22.0)$ \\
Muscle relaxation (VAS - cm) & $7.2(5.8-8.6)$ & $7.3(6.3-9.8)$ & $7.4(6.0-8.3)$ \\
Recovery (min) & $28.0(23.8-54.8)^{\mathrm{a}}$ & $240.0(73.0-288.0)^{\mathrm{b}}$ & $204.0(97.0-266.3)^{\mathrm{b}}$ \\
Skin temperature at baseline $\left({ }^{\circ} \mathbf{C}\right)$ & $26.4 \pm 0.5$ & $26.7 \pm 1.6$ & $26.5 \pm 0.6$ \\
Skin temperature at $\mathbf{6 0}$ min $\left({ }^{\circ} \mathbf{C}\right)$ & $26.7 \pm 0.5$ & $27.1 \pm 0.7$ & $26.8 \pm 1.1$ \\
\hline
\end{tabular}

For each variable (within rows), treatments with a superscript in common are not significantly different $(p<0.05)$. (Dunn's multiple comparison test; $p<0.05$ ). Source: Research data.

\section{Conclusions}

Under the conditions of this research, the combination of butorphanol or midazolam with ketamine did not improve the degree of analgesia or muscle relaxation in red-footed tortoises. However, the combinations prolonged the recovery from anesthesia when compared to the sole use of ketamine. Thus, the results of this study do not support the combination of butorphanol or midazolam with ketamine for farmacological restraint of red-footed tortoises.

\section{Acknowledgements}

Maria Guadalupe Dias Pestana Santos would like to thank UVV (Centro Universitário Vila Velha) and FAPES (Fundação de Amparo à Pesquisa do Espírito Santo) for the financial assistance during these studies.

\section{References}

BIENZLE, D.; BOYD, C. J. Sedative effects of Ketamine and midazolam in snapping turtles (Chelydra serpentina). Journal of Zoo and Wildlife Medicine, v. 23, n. 2, p. 201204, 1992.

HOERNERCUBAS, P.; BAPTISTOTTE, C. Chelonia (tartaruga, cágado, jabuti). In: CUBAS, S. C. et al. (Ed.). Tratado de animais selvagens. São Paulo: Roca, 2007. p. 86-92.
MATHEWS, K. A. Pain assessment and general approach to management. Veterinary Clinics of North America: Small Animal Practice, v. 30, n. 4, p. 729-755, 2000.

MCARTHUR, S. Anaesthesia, analgesia and euthanasia. In: MCARTHUR, S. et al. (Ed.). Medicine and surgery of tortoises and turtles. Oxford: Blackwell Publishing, 2004. p. 379-401.

SCHUMACHER, J. Reptile and amphibian anesthesia. In: THURMON, J. C. et al. (Ed.). Veterinary anesthesia. Baltimore: Williams and Wilkins, 1996. p. 670-685.

SCHUMACHER, J. Chelonians (Turtles, Tortoises, and Terrapins). In: WEST, G. et al. (Ed.). Zoo animal and wildlife immobilization and anesthesia. New Jersey: John Wiley \& Sons, 2007. p. 259-266.

SLADKY, K. K. et al. Effects of opioid receptor activation on thermal antinociception in red-eared slider turtles (Trachemys scripta). American Journal of Veterinary Research, v. 70, n. 9, p. 1072-1078, 2009.

WAGNER, A. E. Opioids. In: GAYNOR, J. S.; MUIR, W. W. (Ed.). Handbook of veterinary pain management. St Louis: Mosby, 2002. p. 164-183.

Recebido: 05/01/2011

Received: 01/05/2011

Aprovado: 22/09/2011

Approved: 09/22/2011 